\title{
Progressive vs modular system in preparatory school English language teaching program: A case of system change at a state university in Turkey
}

\author{
Ali Erarslan ${ }^{a} *$ (iD \\ APA Citation: \\ ${ }^{a}$ Alanya Alaaddin Keykubat University, Alanya, Antalya , 07450, Turkey \\ Erarslan, A. (2019). Progressive vs modular system in preparatory school English language teaching program: A case of system change at a \\ state university in Turkey. Journal of Language and Linguistic Studies, 15(1), 83-97. \\ Submission Date:19/06/2018 \\ Acceptance Date:19/01/2019
}

\begin{abstract}
Due to its importance in almost all significant fields such as science, technology, education and trade, English language is offered as a compulsory course in all levels of formal education in Turkey. In the higher education context, most universities offer one-year compulsory English preparatory education for students enrolled in departments whose medium of instruction is in English. Commonly, the two systems existing in preparatory programs known as modular system and progressive system enact the legislation and organization of courses as well as the assessment, classroom procedures and material design. In progressive system, English education is offered throughout the year based on learners' level of English according to the placement test given at the beginning of the education year; on the other hand, in modular system English is taught in different modules at the same time allowing learners to move forward or fall behind their current levels. Because of the poor English levels of the preparatory class students at a state university in Turkey, a system change from a progressive system to a modular one took place which started to be implemented from 2015-2016 academic year onwards. For the purpose of evaluating both systems, English language instructors' views related to strengths and weaknesses of the modular and progressive systems were gathered through a semi-structured opinion form. The data were gathered from 23 participants who actively taught English in the both systems and were analysed through inductive content analysis. Findings of the study show that the participants found the modular system effective and efficient since students were placed in their correct levels of English unlike in the progressive system and since they were assessed based on their current level of English, Additionally, the participants favoured the modular system due to well-planned placement system in each module although they reported that modular system caused confusion on the part of the instructors because of the frequent exams and quizzes applied within a limited period. Besides, delivering English in more than one module at a time also caused the instructors to feel under pressure and a burden. As for progressive system, it was found that it was practical in terms of planning and organization in spite of decreasing student motivation. These findings indicate that although instructors find modular system effective and efficient, it needs a good planning and organization.
\end{abstract}

(c) 2019 JLLS and the Authors - Published by JLLS.

Keywords: Preparatory education; EFL; higher education; modular; progressive

\section{Introduction}

\footnotetext{
* Corresponding author. Tel.: +90 242 5106060/3038

E-mail address: ali.erarslan@ alanya.edu.tr
} 
Today, being the lingua franca of the 21st century meeting the communicative needs of the global world in the fields of international politics, economy, science and education, English language is taught as a second or a foreign language in schools embedded into the national curricula of many countries across the world (Dogancay-Aktuna, 1998). Global influence of English language has created a great demand and need to have knowledge of English and use it for communicative purposes (Cholakova, 2015; Nunan, 2003). Due to this influence and significance of English language, it is also integrated into Turkish national education as a foreign language (EFL) being offered in all levels from primary education to tertiary level.

In terms of basic education from primary to high school education, English is taught a compulsory course beginning from the second grade onwards in Turkey with the aim of exposing students more to the language because of the effects of globalization as well as social, political and economic factors (Kirkgoz, 2007). In primary education, one of the major drives for teaching English students, from grade 2 onwards, is to enable students become efficient users of the language for communicative purposes. Additionally, creating a positive affection towards language learning (Alkan \& Arslan, 2014; Ar1, 2014; Cihan \& Gürlen, 2009; İyitoglu \& Alci, 2015; Şad, 2011; Seçkin, 2010; Yıldıran \& Tanrıseven, 2015) is also another aim of teaching English in primary education.

Regarding higher education, English is offered as a mainstream course in Turkey which students need to take regardless of their departments or length of university education. Although the medium of instruction is Turkish (Turkish Medium Instruction-TMI) in most state universities, in a growing number of universities, students receive their courses only in English (English Medium Instruction-EMI) (Karakaş, 2015; Öner \& Mede, 2015) since, as Kirkgöz (2014) states, it is regarded as prestigious and advantageous in terms of finding high salary jobs. Regarding this, the medium of instruction is facing an increasing shift from pure TMI to a combination of EMI or TMI + EMI (TEPAV \& British Council, 2015 ) where students receive content education solely in English (100\%) or both in Turkish (70\%) and English (30\%) languages (YOK, 2014). With the aim of fulfilling the increasing demand for providing students studying at EMI and TMI+EMI universities with the necessary linguistic knowledge, a oneyear English preparatory education is offered both in elective and compulsory manner (Öner \& Mede, 2015; West et al., 2015).

Students at preparatory schools in Turkey receive language education to become proficient in English not only for fulling the language needs required to pass their departmental courses but also for their professional life (Sarıçoban \& Sarıçoban, 2012). In these schools, the intensive one-year language education focuses on four language skills in addition to language areas. However, it is a commonly known fact that a majority of the students who exit preparatory schools completing the English language education fall behind the language requirements of their departments because of the failures of the preparatory schools in preparing students for their academic life. One of the reasons for this failure is that preparatory schools are generally designed to provide general English to students rather than taking their departmental and professional language needs into consideration (Coşkun, 2013). A recent report published by British Council (2015, p.115) highlights that one-year intensive language education is too short to reach the target language proficiency on the part of the students and it is stated in this report that English language teaching in Turkish universities does not give support to the academic programmes and internationalisation.

Program evaluation in education plays a crucial role in terms of using the collected data to make judgments and giving decisions (Lynch, 1996) related to the program in implementation. As Brown (1995) mentions, program evaluation is systematic and is conducted for the purpose of improvement of an education program as well as understanding its effectiveness. In fact, education programs change constantly to meet the requirements of the changing conditions of countries; thus they need to be evaluated to determine whether the intended change has taken place (Frye \& Hemmer, 2012). Given the 
significance of preparatory school English language teaching programs in higher education, it is apparent that there is an urgent need to evaluate the preparatory school systems considering the students' insufficient English learning output from these schools in Turkey. Thus, this study focuses on evaluating both progressive system and modular system from the lenses of the academics who implemented both systems.

\subsection{Literature review}

Regarding the evaluation of preparatory school English language teaching programs in Turkey, a number of evaluation studies were conducted. To begin with, one of the earliest studies evaluating the preparatory English programs was conducted by Gerede (2005). In her study Gerede evaluated the intensive preparatory English programs after a curriculum renewal project from the perspective of students' language needs in their departments. Investigating whether the former or the latter program sufficiently met the needs of the students, it was found that the new program was satisfactorily more effective than the previous one in terms of meeting the students' language needs. Similar to the focus of this current study, Gerede's (2005) findings in evaluating the new program in comparison to an earlier one indicate the significance of renewing the education programs when necessary.

Similarly, in order to evaluate the effectiveness of a state university preparatory English language teaching program, Tunç (2010) conducted a study in which 406 preparatory school students and 12 academics participated and she found that the preparatory school partially contributed to student learning when its purpose was taken for granted. Additionally, Tunç (2010) also found that students were poor in using the language for communication; in line with this, the preparatory education program required a number of amendments in terms of the physical conditions as well as the program aspects such as content, material, testing and assessment.

Other studies conducted also found a number of striking findings regarding English language teaching programs in preparatory schools in Turkey (see İnal \& Aksoy, 2014; Öner \& Mede, 2015) . Based on these studies, content delivered in preparatory schools to students did not match with their departments and students were not sufficiently prepared for their departments, especially low-level ones. Additionally, students could not be equipped with the necessary language skills to communicate in their preparatory education.

As for the scope of this study, there is only one study found in literature which was conducted by Coşkun (2013) addressing to a part of this study. Evaluating the modular system intensive preparatory English language teaching program in a state university in Turkey from student and academics' perspectives, Coşkun's study yielded a number of significant results regarding the effectiveness of modular system implemented in preparatory education in terms of insufficient instructional materials and lack of student-centred activities lowering the quality of language education. The case of repeat students was also regarded as an obstacle in the implementation due to their low level motivation. Apart from this, modular system was also ineffective because of the resources of the school in providing the repeat classes with the extra materials and academic assignment due to lack of enough number of academics.

Thus, based on the review of the a number of studies conducted to evaluate the preparatory English language teaching programs of various both state and private universities, it is clearly seen that English preparatory schools in Turkey fall behind preparing sufficiently the students to their departments with the necessary linguistic knowledge not only for general purposes but for their academic purposes as well. As stated by some other studies (see also Kirkgöz, 2014; Mede \& Akyel, 2014; Mede \& Serkan, 2014), preparatory schools in Turkey have failures in equipping students with the necessary linguistic knowledge and need amendments in a number ways such as program design and physical conditions. 
When systems in these schools are taken into consideration, it is quite clear that most preparatory schools make use of progressive system; however, apart from progressive system, a number of preparatory schools are based on modular system and in the light of literature not a single study evaluating both progressive and modular system preparatory English language teaching programs in Turkey exists. Thus, this study, being the first of its kind, aims to contribute to literature and fulfil this gap by evaluating a state university preparatory English language teaching program from both progressive and modular system aspects.

\subsection{Context of the study}

The context of this study is a state university, Pamukkale University, in Turkey. Founded in 2007, preparatory school offers intensive English preparatory education for students enrolled in departments which deliver content education in English partly or fully as the medium of instruction. Due to the concerns voiced by these departments regarding their students' insufficient linguistic knowledge after preparatory education to follow departmental courses, a change from progressive system to modular system took place in 2015-2016 teaching year after an intensive design process.

\subsubsection{Progressive system implementation and transition to modular system}

In progressive system, which is the most commonly used system in preparatory schools in Turkey, students need to have two exams just before the start of teaching year; a proficiency exam in B2 level as the threshold and a placement test for those who fail to pass the proficiency exam. Based on students' scores in the placement test, they are placed in a class in accordance with their level of English. In the context of this study, three distinctive levels as Elementary, Pre-Intermediate and Intermediate were used for the placement of the students which students used to follow in a linear way by moving further with the following levels. Having no flexibility among levels, all students, following the same class with the same academics, were to take the final proficiency exam at the end of the year and would succeed the preparatory education or fail for the next year. Due to the above mentioned complaints about English education, the school board decided to replace progressive system with the modular one with the aim of improving the quality of language education by enhancing students' knowledge of English and the transition took place in the 2015-2016 teaching year after a number of steps;

1. Bilateral meetings with the administration and academic members and establishment of commissions assigned for the investigation of implementation, legal regulation and administrative aspects of modular system.

2. Scrutinizing several universities in Turkey and visiting them for investigating their resources, number of academics and students as well as likely obstacles and legal challenges that would arise during the implementation. ,

3. Inviting academics and administrators from other universities to give detailed information and presentation regarding modular system to the academic members of the preparatory school.

4. Working on and designing the legal regulations, the acceptance step for the transition to modular system legally by university senate and the announcement of legislation after being published in Official Gazette in 2016 (for detailed information, see http://mevzuat.basbakanlik.gov.tr/Metin.Aspx?MevzuatKod=8.5.14161\&MevzuatIliski=0\&sourceXml Search=Yabanc\%C4\%B1\%20Diller\%20Y\%C3\%BCksekokulu).

\subsubsection{Implementation of Modular System}

Based on the level descriptors of CEFR, the module system have five basic language levels as A1, A2, B1,B2, C1 and pre-faculty level which aims at making students focus on their departmental subjects through ESP and EAP instruction. The two term period in progressive system is increased to four equal 
terms for 8 weeks in each module. One of the most distinguishing feature of the modular system is its flexibility allowing students to pass higher modules by skipping the following module or even to finish the preparatory education in the middle of the teaching year. On the other hand, when the students cannot progress, they fail in the same module and repeat it for another 8 weeks. Another striking change brought by the initiation of the modular system is in the exam system. In order to make students proficient users of English, Core English, Reading, Writing, Listening and Speaking course CEFR based outcomes have been brought into conformity with the exam system. The weekly 20 -hour instruction is embedded into regular quizzes, module midterms and module final exams apart from the alternative assessment types such as portfolios and presentations in addition to individual and group tasks-projects for each course. The pass grade for each module is 70 out of 100 and students' grades are calculated based on exam/assessment types as shown in Table 1 below.

Table 1. Distribution of exams and their ratio for each module

\begin{tabular}{lc}
\hline Exam/Assessment Type & Ratio \\
\hline Midterm & $30 \%$ \\
Quiz & $10 \%$ \\
$\begin{array}{l}\text { Alternative Assessment } \\
\text { (Portfolio, project etc.) }\end{array}$ & $10 \%$ \\
Module Final Exam & \\
\hline
\end{tabular}

\subsection{Research questions,}

This study aimed at exploring the academics' opinions regarding both progressive and modular system preparatory school English language teaching program following a transition from progressive system in a state university in Turkey. In this context, the study poses three research questions as follows;

1- What are academics' opinions regarding the strengths and weaknesses in the implementation of the modular system?

2- What are academics' opinions regarding the strengths and weaknesses in the implementation of the progressive system?

3- Which of these systems do the academics' prefer in preparatory English language teaching program?

\section{Method}

Since the primary purpose of this study is to gain an insight into the academics' opinions regarding progressive and modular system preparatory school English language teaching programs, it is designed as a descriptive survey study making use of qualitative research approach.

\subsection{Participants}

The participants of this study are the academics' teaching English to preparatory school students at Pamukkale University who actively experienced both progressive system and modular system. In this respect, 23 academics participated in the study through purposeful sampling. 
Table 2. Participant demographics $(n=23)$

\begin{tabular}{cc}
\hline Variable & Percentage \\
\hline Gender & 74 \\
Female & 26 \\
Male & \\
Age & 21.7 \\
$26-30$ & 52.1 \\
$31-35$ & 21.6 \\
$36-40$ & 4.6 \\
$41+$ & \\
Graduation & 56.5 \\
English Language Teaching & 30.4 \\
English Language \& Literature & 4.3 \\
Translation Studies & 8.7 \\
American Language\& Literature & \\
Teaching Experience in Preparatory Schools & 8.7 \\
1-3 yrs & 34.8 \\
4-6 yrs & 34.8 \\
7-9 yrs & 17.4 \\
10-12 yrs & 4.3 \\
13-15 yrs &
\end{tabular}

\subsection{Data collection \& analysis}

In the collection of the data for the research questions, a semi-structured survey form was developed and following expert opinions, the form was revised consisting of questions related to strengths and weaknesses both systems. Then it was delivered to the academics in the 2016-2017 teaching year during an academic meeting related to the implementation of the modular system. The data gathered were analysed through content analysis focusing on the arising themes and categories commonly. Upon the identification of the themes and categories, the data were presented qualitatively.

\section{Results}

Following the analysis of the data, arising themes and categories for each research question have been tabulated and presented starting from academics' opinions of modular system first, progressive system the next and their preferences of these systems the last.

\subsection{Common characteristics of modular system}

Data analysis regarding academics' opinions on the common characteristics of the modular system yielded a number of categories and themes. Based on their opinions, modular system had both strengths as well as weaknesses.

Related to the strengths, the modular system was regarded as an active system linked to student motivation and alertness. Regarding this, A1 expressed that "Modular system is an active system, every 
eight weeks we change the classes and teachers. Each module keeps the students alert fearing for failure. Thus, they have to study hard to pass the following module". Additionally, A20 stated "In this system students are exposed to exams in 8 weeks and they have to time to lose. The system keeps students alert and active."

Table 3. Strengths and weaknesses of modular system

\begin{tabular}{|c|c|c|}
\hline & on Characteristics & Participant Code \\
\hline \multirow{4}{*}{ 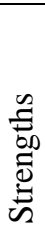 } & Activeness & $\mathrm{A} 1, \mathrm{~A} 3, \mathrm{~A} 4, \mathrm{~A} 7, \mathrm{~A} 11, \mathrm{~A} 15, \mathrm{~A} 19, \mathrm{~A} 20$ \\
\hline & CEFR Compatibility & $\mathrm{A} 1, \mathrm{~A} 2, \mathrm{~A} 9, \mathrm{~A} 20, \mathrm{~A} 22$ \\
\hline & Level Progress & $\mathrm{A} 1, \mathrm{~A} 2, \mathrm{~A} 5, \mathrm{~A} 7, \mathrm{~A} 8, \mathrm{~A} 12, \mathrm{~A} 17, \mathrm{~A} 20, \mathrm{~A} 21, \mathrm{~A} 23$ \\
\hline & Student Development & $\mathrm{A} 3, \mathrm{~A} 4, \mathrm{~A} 5, \mathrm{~A} 6, \mathrm{~A} 8, \mathrm{~A} 10, \mathrm{~A} 13, \mathrm{~A} 15, \mathrm{~A} 18, \mathrm{~A} 19, \mathrm{~A} 20$ \\
\hline \multirow{4}{*}{ 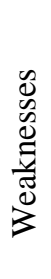 } & Time Constraint & A2, A3, A7, A9, A10, A11, A13, A15, A18, A19 \\
\hline & Exam Intensity & A3, A6, A8, A13, A15, A18, A19, A22, A23 \\
\hline & Work Load \& Burden & $\begin{array}{c}\mathrm{A} 1, \mathrm{~A} 3, \mathrm{~A} 5, \mathrm{~A} 6, \mathrm{~A} 8, \mathrm{~A} 9, \mathrm{~A} 11, \mathrm{~A} 16, \mathrm{~A} 18, \mathrm{~A} 19, \mathrm{~A} 20, \\
\mathrm{~A} 22, \mathrm{~A} 23\end{array}$ \\
\hline & Student Acquaintance & $\mathrm{A} 2, \mathrm{~A} 7, \mathrm{~A} 10, \mathrm{~A} 21$ \\
\hline
\end{tabular}

Another point highlighted as a strength of the modular system by the academics is that basing the system on the level descriptors of CEFR was a striking characteristic for the participants. Regarding this, A9 explained that "In the previous system we did not exactly know what the outcomes were for Elementary or Intermediate levels; however, I am aware of what to do for each module now." Likewise, A22 stated "All around the school are "CEFR outcome tables for students and instructors. Students know what they are responsible for in the exams in each module. Also instructors have the confidence in what to expect from students in each module."

Related to modular system, academics held the opinion that modular system did not allow students to go further modules unless they obtained the required student outcomes specified. Considering the 8week teaching and learning period for each level, students have certain segmented goals to complete and pass the module. Thus, with the help of defined CEFR outcomes students may compensate their weaknesses in the given limited time unlike previous system. Regarding this, A1 expressed that "Students in modular system have to study and be ready for the lessons otherwise they know they will fail. No one can pass a module if they do not get proficiency in that language level." In a similar vein, A17 also stated that "Students do not have to wait until the end of the year to understand how much they progressed. This is the best opportunity for them. In fact, this system is efficient in that it prevents time loss on the part of the students."

Regarding student development, modular system, as voiced by academics, is considered to be contributing to students' language development. Academics regarded modular system as a strength allowing students reach proficiency by dividing the process into short but intense sections promoting student learning through module based activities and assessment. Related to this, for instance, A13 expressed that "Students now have to develop themselves inevitably, because module system gives them chance to build knowledge upon what they already know by pushing them forward." Thus, they reach level proficiency and build upon it in other modules. Regarding the same issue, another participant, A15 expressed that "in this system, students do really learn. They get accustomed to classroom changes and they are aware that if they stop, they will fail suddenly." 
The participant academics' opinions regarding the modular system were not without criticisms. While they stressed a number of positive aspects of this system, at the same time, some weaknesses were also reported. These drawbacks the academics mentioned were grouped under the themes of time constraint, exam intensity, work load and burden on academics and academic units, organization and resources as well as student acquaintance.

In terms of time constraint, the academics were of the opinion that 8-week education period allocated for each module was too limited to cover the specified content and reach the aims. Regarding this they also added that frequent exams and quizzed shortened the period and a total of 6 weeks were utilized. In relation to this, A7 stated that " 8 -weeks instruction is not enough especially for B1 and B2 modules." Similarly, A11 complained about the interrupts caused by the class organizations and exams by saying "8-week time is quite limited because the first week is missing because of classroom organizations and a week is missing for the exams. We have only 6 weeks left to deliver the content".

Related to the theme of exam intensity, as briefly explained above, participants claimed that there were too many exams and pop-up quizzes implemented in a short time hindering the smooth flow of the instruction in a module time. For this reason, academics felt under pressure and could not focus on extra activities to enhance learning. In relation to these, for example, A 18 stated that "In modules, I cannot do what I really want to do because I have to teach the content to students without doing extra things just for the exams and quizzes. Students also want things just for the exams."

Regarding work load and burden the modular system brings on the academics, the participants were of the opinion that intense works and organizational requirements of modular system made the academics inefficient in their teaching and feel under burden. Related to this, A3 stated:

"Because of exams, we have to read and assess student papers in midterms, quizzes, final exams.

For the next module, we do not know what module and language skill to teach. We cannot get prepared enough for the lessons due to the works of modular system."

Similarly, academics also complained for the work load in academic units of Material Development and Exam Center and Testing as well as the management work load for assigning new and repeat classes, academics to these classes and organizing material and testing units for the preparation of material packs, exams and resources. Regarding this, two of the academics (A9 and A16) reported that modular system, in fact, required lots of extra work compared to progressive system by stating "In the middle of each module, we start thinking about the following modules for exams, classes since we cannot guess how many new classes and repeat classes will be available. We were comfortable in the previous system" (A9).

As the final reported weakness, the modular system did not allow academics to know about their students in terms of their learning needs to address when necessary. Additionally, it was explained that for an effective teaching-learning process on both parties, academics needed to be familiar with their students to help them better in their learning taking their features into account. Regarding this issue, one of the academics (A2) explained that "Eight-week module period does not allow us to recognise our students and we cannot help them properly when they need. We need time to explore their learning habits so that we can help them." In the same vein, another participant, A 10 stated that "Each module ends just as we start to learn about the students' characteristics."

When all aspects regarding modular system are taken into consideration as the findings of this study, it is seen that academics' stated modular system was an active one providing flexibility among language levels. Additionally clearly defined outcomes as specified by CEFR and using them in module levels were found to be a strength of the modular system. Another finding showed there is a clear match between students' level and module level which also contributes to the development of the students in their language learning. However, academics also had the opinion that dividing each module into eight- 
week segments was regarded as a limitation not allowing the implementation of varied classroom activities. Likewise, the flood of exams applied in limited module duration challenged academics in using teaching time efficiently. Since new module classes together with repeat classes arise in every eight weeks' time, the academic units need to plan and execute the necessary operations over and over especially in preparing materials and exams which sometimes brought extra burden on the academics. Finally, academics complained that modular system did not allow academics to know about their students in-depth and address their needs in their teaching.

\subsection{Common characteristics of progressive system}

Regarding progressive system, which had been implemented for nearly 9 years until the implementation of the new modular system, participant academics were asked for their opinions and in relation to its strengths and weaknesses, a number of themes were identified as explained below.

Table 4. Strengths and weaknesses of progressive system

\begin{tabular}{|c|c|c|}
\hline & Common Characteristics & Participant Code \\
\hline \multirow{2}{*}{ 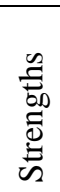 } & Time Advantage & $\mathrm{A} 1, \mathrm{~A} 3, \mathrm{~A} 4, \mathrm{~A} 8, \mathrm{~A} 11, \mathrm{~A} 15, \mathrm{~A} 19, \mathrm{~A} 20$ \\
\hline & Use of Materials/Resources & $\mathrm{A} 1, \mathrm{~A} 2, \mathrm{~A} 9, \mathrm{~A} 20, \mathrm{~A} 22, \mathrm{~A} 23$ \\
\hline \multirow{3}{*}{ 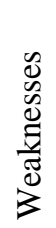 } & Student Success/Motivation & $\mathrm{A} 2, \mathrm{~A} 3, \mathrm{~A} 5, \mathrm{~A} 8, \mathrm{~A} 15, \mathrm{~A} 17$ \\
\hline & Student Attendance & $\mathrm{A} 1, \mathrm{~A} 2, \mathrm{~A} 3, \mathrm{~A} 4, \mathrm{~A} 5, \mathrm{~A} 8, \mathrm{~A} 10, \mathrm{~A} 13$ \\
\hline & Classroom Management & $\mathrm{A} 6, \mathrm{~A} 7, \mathrm{~A} 9, \mathrm{~A} 11, \mathrm{~A} 11, \mathrm{~A} 14, \mathrm{~A} 20$ \\
\hline
\end{tabular}

According to academics' views, one of the definite advantages of the progressive system was the time advantage it offered to both the students and the academics. Regarding this aspect, it was reported that progressive system enabled especially slow learners to gain time to compensate the gap in his/her learning. Similarly, academics also held the opinion that they were able to apply various activities and methods in their teaching as well as adjusting the pace of their teaching based on the progress of the students. In relation to this, some academics stated that "In progressive system, we did not need to hurry to catch up with the syllabus. We had enough time to do lots of activities in the class." (A8). Adding more to these views, A19 also expressed that "I prefer modular system, but in progressive system slow learners had the opportunity to catch the rest of the class over time if they wanted to."

Another positive aspect of the progressive system was the efficient use of materials and school resources such as classes, academic staff, and other organizational issues. An intensive planning and organizational work were utilized just at the very beginning of the teaching year and apart from the minor ones, no extra major changes were required until the end of the teaching year. Regarding this, A1, expressed that "In the previous system (progressive system), everything was planned once and never changed. Material Office and Testing Office prepared their materials and exams at the beginning and continue with the initial plan smoothly throughout the year." In terms of school management, A23 stated that "Progressive system offered advantages only for the school management because just after the placement exam, all the classes and academics to these classes were assigned; materials were prepared in advance in addition to creating an exam pool." 
In fact, more negative aspects were voiced by the academics compared to strengths of the progressive system. Based on the claims uttered, students in the progressive system mostly failed either because of the lack of motivation caused by following the same rigid routine for a whole year or due to mismatch between students' exact level of language and the one placed based on the exam at the beginning. It was expressed that after certain amount of time, students became disinterested in the lessons especially if they were false beginners. Additionally, when the students fell behind the class level, they became demotivated and followed that level without having chance to compensate the gap. Specifically, some of the participants explained this aspect in detail. For example, A3 stated that "Once the students in the previous system experienced failure in one of the exams at the beginning, they were lost and demotivated and they had to continue their education without paying attention."

Another finding was related to student attendance in progressive system. Based on the academics' views, students had problems in attending the classes regularly. In fact, another factor causing student failure in progressive system was the case of attendance and dropout rate especially for elective students. In this respect, A4 stated that "One of our challenges in progressive system was that students failed because of not attending the classes. The more students lost their enthusiasm towards learning English, the more they preferred being away from school and they finally failed or dropped out." In the same manner, A13 also explained that "Compulsory students want to study but if there are more elective students in the class, they start to behave freely because there is no sanction imposed against them in case of failing in preparatory school."

The last reported weakness of the progressive system was related to classroom management challenges on the part of the academics. Students' acquaintance with their peers and teachers for a long time especially combined with the low-level classes created discipline problems in participating the classroom activities and completing the course requirements. In this issue, A10 expressed "when students experienced a challenge in learning the language, they just gave up and came to classes as a foreigner and lost their ambitions." The other participant A20, similarly, explained that "Progressive system did not work because students could not guess whether they would succeed or not, for this reason they tended to skip classes or did not do anything in the class for learning."

As a brief summary of the findings regarding academics' opinions about progressive system, it was found that a yearlong rigid teaching time was regarded as a strength of the progressive system allowing students and the academics to compensate any gap in the teaching and learning process. Additionally, organizing all the school resources from teaching staff to classes or organizing classroom materials and exams only once at the very beginning of the teaching year was seen as another strength. However, a number of drawbacks regarding the progressive system were also found all of which were related to student factor. Progressive system was found to be ineffective in equipping students with the necessary linguistic knowledge due to the factors such as student motivation, student attention and classroom management.

\subsection{Academics' preferences of progressive or modular system}

The final research question posed in this study aimed at gaining insight into the academics' preference of progressive and modular system since the participants all took place in the implementation processes of both systems. Based on their responses, it is seen that although it contained a number of weaknesses, they embraced modular system. Table 5 below shows the percentage of academics' preferences regarding progressive and modular system. 
Table 5. Academics' preferences of progressive or modular system

\begin{tabular}{cccccc}
\hline & & Frequency & Percent & Valid Percent & Cumulative Percent \\
\hline \multirow{3}{*}{ Valid } & Progressive & 5 & 21,7 & 21,7 & 21,7 \\
& Modular & 18 & 78,3 & 78,3 & 100,0 \\
& Total & 23 & 100,0 & 100,0 & \\
\hline
\end{tabular}

As Table 5 shows, a great majority of the academics, $78.3 \%$, preferred modular system for implementation in the preparatory school based on the reasons as explained in the previous research question. However, it is also seen that 21.7 of the academics also found progressive system more preferable than the modular system although their percentage was low. Thus, it is clear that academics in a state university preparatory school favoured modular system since it is believed to contribute more to student learning.

\section{Discussion}

From the findings of the study, it was found that modular system was found to be effective in terms of donating the university students with the required linguistic knowledge in English due to its active nature and flexibility among module levels rectifying the inequality between students' actual level of the language with the module level. As Gonzales (2011) states when the mismatch between students' level and the placed level in language education is prevented with a valid and reliable placement test, it provides increased student learning and retention. Additionally, in modular system students are motivated and their preparedness to learn is high. It is a well-known fact based on literature that motivation is a key concept for success (Williams and Burden, 1997; Gardner, 1985) especially in language learning. One of the reasons why modular system offers advantages to students for their success in their language learning process might be related to issue that success has to do with the extent to which students struggle for reaching the purpose of learning the language since each module offers short term attainable goals for the students. Another strength alleged regarding the modular system was the CEFR based outcomes aligned with exam content. As Kir and Sülü (2014) explain CEFR based language teaching programs in Turkey are increasing in number and studies indicate the effectiveness of these CEFR based programs. In fact as also asserted by Cephe and Toprak (2014), exams taking CEFR descriptors into core try to assess what a learner at certain level can do; thus, course books are also designed or chosen with regard to their proximity with CEFR levels. This may explain why student motivation and their sense of accomplishment in modular system is increased. It can also be argued that other positive strands regarding modular system as found in this study, i.e. level progress and student development are all considered to be related to CEFR-exam-material alignment as stated above.

Modular system came along with some negative aspects as found in this study. The most prominent one was related to difficulty of organization and use of resources. The major source of this difficulty is the case of repeat classes. This finding is also supported by Coşkun (2013). Based on his study on modular system, he found that one of the challenges of modular system was the efficient use and allocation of resources stemming from repeat classes making the implementation of modular system quite difficult due to contextual limitations like enough number of academics, classrooms and other school resources which also appeared in this study. However, from the perspectives of the academics in this study, modular system seems promising for preparing students to their academic and social life with the necessary linguistic knowledge when compared to progressive system.

Findings regarding progressive system were in fact just contradictory to modular system. It is seen that progressive system did not yield the desired attainments of the program goals. Providing convenience for organization and use of resources, the progressive system is reported to cause classroom 
management challenges in addition to increased dropout rates with common student failures. In fact, it is true that most of the universities in Turkey have progressive system in their implementation of preparatory language teaching programs and studies show that there are a number of deficiencies in these programs such as resources, physical conditions of schools, program components and especially in terms of offering academic English or ESP (Coşkun, 2013; İnal \& Aksoy, 2014; Özkanal \& Hakan, 2010). According to these studies, the common problem for preparatory education was the mismatch between the expectations of the students and departments from the type of instruction offered in preparatory schools. In fact, most preparatory school English teaching programs in Turkey, either modular or progressive, offer English for General Purposes (EGP) contrary to expectations such as English for Specific Purposes (ESP) or Academic Purposes (EAP) (Coşkun, 2013; Kirkgoz, 2009). This issue is resolved in modular system by an addition of "academic module" above B2 level which aims to offer language education to students with intensive reading and terminology specific to students' department.

\section{Conclusions}

Set out to reveal academics' opinions on two systems applied in a preparatory English language teaching programs at a state university in Turkey, this study came out with a number of conclusions. Initially, the progressive system is a practical one in terms of management and organization and can be applied even in limited-source schools; however, when program aims and outcomes are ambiguous, as in the case of this study, or at least if academics follow just the routine of the course books, a probable inconsistency in the assessment and the content covered during the courses may arise and this may be linked to a decrease in students' motivation and willingness to learn. On the other hand, this may be solved by aligning level descriptors, namely outcomes, and testing and assessment criteria.

For modular system, it can be concluded that it can be effectively applied even in state university preparatory schools and setting short term goals for the students, it increases students' motivation and preparedness to learn. CEFR descriptors and aligned tests fruitfully increases students' sense of accomplishment. An addition of an academic pre-faculty module partially solved the conflict of EGP and EAP. However, from the literature it is possible to conclude that for an effective implementation of modular system resources of the school needs to be enough and be efficiently utilized.

Not but not least, none of these systems are able to yield the desired effects regarding preparing students to their departments since there are several other internal factors intervening in the process of language learning. Yet, academics as the participants in this study supported modular system since the major obstacles in progressive system were surpassed indicating that a change is crucial when the intended and experienced curricula do not correlate with each other. Thus, as a final remark, it is possible to conclude that such a program change.

\section{References}

Alkan, M. F., \& Arslan, M. (2014). Evaluation of the 2 nd Grade English Language Curriculum. Uluslararası Eğitim Programları ve Öğretim Çalışmaları Dergisi, 4(7), 87-99.

Ar1, A. (2014). Teacher Opinions About Evaluation of 6th Grade English Lesson Curriculum in Primary Schools. Journal of Theoretical Educational Science, 7(4), 172-194. 
British Council-TEPAV. (2015). The state of English in Higher Education in Turkey: A Baseline Study. British Council.

Brown, J. (1995). The elements of language curriculum A Systematic Approach to Program Development. Boston: Heinle \& Heinle Publishers.

Cephe, P. T., \& Toprak, E. T. (2014). The Common European Framework of Reference for Languages: Insights for language testing. Journal of Language and Linguistic Studies, 10(1), 7988 .

Cholakova, M. (2015). The Influence of the English Language in a Multilingual and a Monolingual Environment - A Comparative Approach. International Journal of English Language Teaching, $3(4), 35-78$.

Cihan, T., \& Gürlen, E. (2009). Teachers' Opinions on the English Language Curriculum of the 5 th Grade of Primary Education. Anadolu Universitesi Sosyal Bilimler Dergisi, 13(1), 131-146.

Coşkun, A. (2013). An investigation of the effectiveness of the modular general English language teaching preparatory program at a Turkish university. South African Journal of Education, 33(3), $1-18$.

Damirchili, F., \& Tajari, M. (2011). Explaining internal factors effective on educational quality improvement based on views of students from Zanjan Azad universities. Procedia - Social and Behavioral Sciences, 30, 363-366. https://doi.org/10.1016/j.sbspro.2011.10.071

Dogancay-Aktuna, S. (1998). The Spread of English in Turkey and its Current Sociolinguistic Profile. Journal of Multilingual and Multicultural Development, 19(1), 24-39. https://doi.org/10.1080/01434639808666340

Frye, A. W., \& Hemmer, P. A. (2012). Program evaluation models and related theories: AMEE guide no. 67. Medical Teacher, 34(5), 288-99. https://doi.org/10.3109/0142159X.2012.668637

Gerede, D. (2005). A Curriculum Evaluation Through Needs Analysis: Perceptions of Intensive English Program Graduates at Anadolu University (Unpublished MA Thesis). Anadolu University, Eskişehir.

Gonzales, E. F. (2011). An EFL placement test and its use in a private high school. Open Distance Learning Master of Arts in Teaching English as a Foreign/Second Language (MA TEFL / TESL). University of Birmingham.

İnal, B., \& Aksoy, E. (2014). Çankaya Üniversitesi Hazırlık Sınıfı İngilizce Öğretim Programının Değerlendirilmesi. Journal of Research in Education and Teaching, 3(3), 119-134.

İyitoglu, O., \& Alci, B. (2015). A Qualitative Research on 2nd Grade Teachers ' Opinions about 2nd Grade English Language Teaching Curriculum. Elementary Education Online, 14(2), 682-696.

Karakaş, A. (2015). Orientations towards English among English-medium Instruction Students Abstract. Englishes in Practice, 2(1), 1-38. https://doi.org/10.1515/eip-2015-0001

Kir, E., \& Sülü, A. (2014). Language Teachers ' Views on Cefr. International Online Journal of Education and Teaching, 1(5), 358-364. Retrieved from http://iojet.org/index.php/IOJET/article/view/69/97

Kirkgoz, Y. (2007). English Language Teaching in Turkey: Policy Changes and their Implementations. RELC Journal, 38(2), 216-228. https://doi.org/10.1177/0033688207079696 
Kirkgöz, Y. (2014). Students' Perceptions of English Language versus Turkish Language Used as the Medium of Instruction in Higher Education in Turkey. Turkish Studies, 9(12), 443-459.

Lynch, B. K. (1996). Language program evaluation: Theory and practice. Melbourne Australia: Cambridge University Press. Retrieved from https://books.google.com/books?hl=en\&lr=\&id=uhE0gJlvcoMC\&pgis=1

Mede, E., \& Akyel, A. S. (2014). Design of A Language Preparatory Program : A Case Study. Journal of Theory and Practice in Education, 10(3), 643-666.

Mede, E., \& Serkan, U. (2014). Evaluation of a language preparatory program : A case study. ELT Research Journal, 3(4), 201-221.

Nunan, D. (2003). The Impact of English as a Global Language on Educational Policies and Practices in the Asia-Pacific Region. TESOL Quarterly, 37(4), 589. https://doi.org/10.2307/3588214

Öner, G., \& Mede, E. (2015). Evaluation of A1 level program at an English preparatory school in a Turkish university: a case study. ELT Research Journal, 4(3), 204-226.

Özkanal, Ü., \& Hakan, A. G. (2010). Effectiveness of University English Preparatory Programs. Journal of Language Teaching and Research, 1(3), 295-305. https://doi.org/10.4304/jltr.1.3.295305

Sarıçoban, G., \& Sarıçoban, A. (2012). Atatürk and the History of Foreign Language Education in Turkey. The Journal of Language and Linguistic Studies, 8(1), 23-26.

Seçkin, H. (2010). İlköğretim 4. Sinıf İngilizce dersi öğretim programının değerlendirilmesi (Unpublised Doctoral Thesis). Hacettepe University, Ankara.

Tunç, F. (2010). Evaluation of an English Language Teaching Program at a Public University Using CIPP Model (Unpublished MA Thesis). Middle East Technical University, Ankara.

West, R., Güven, A., Parry, J., Ergenekon, T., Aşık, G., Aydın, İ., \& Başıhoş, S. (2015). The state of English in higher education in Turkey:A baseline study. British Council \& TEPAV. https://doi.org/10.1017/CBO9781107415324.004

Yıldıran, Ç., \& Tanrıseven, I. (2015). Teachers' opinions on the English Curriculum of the 2nd Grade Primary Education. International Journal of Language Academy, 3(1), 210-223.

Hazırlık eğitimi İngilizce öğretim programında ilerlemeli ve modüler sistem: Bir sistem değişikliği incelemesi

\section{$\ddot{O} \mathbf{z}$}

Bilim, teknoloji, eğitim ve ticaret gibi önemli alanlardaki öneminden dolayı İngilizce Türkiye'de eğitimin her kademesinde zorunlu ders olarak okutulmaktadır. Yükseköğretim kademesinde ise birçok üniversitede eğitim dili İngilizce olan bölümlerin öğrencileri için bir yıllık zorunlu hazırlık eğitimi verilmektedir. Türkiye'de hazırlık okullarında genellikle ilerlemeli ve modüler sistem adı altında iki farklı sistem uygulanmaktadır. İlerlemeli sistemde öğrenciler yıl boyunca yerleştirme sınavı sonucunda yer aldıkları seviyede ilerlemeli olarak öğrenim 
görürken, modüler sistemde ise öğrenciler dil öğrenmedeki seviye gelişimine göre seviye atlayabilmekte veya mevcut seviyede 8 haftalık eğitimi tekrar almaktadırlar. Öğrencilerin istenilen düzeyde İngilizce bilgisine sahip olmadan hazırlığı tamamlamaları ve konu ile ilgili artan olumsuz geri bildirimler sonucunda bir devlet üniversitesinde 2015-2016 öğretim yılında ilerlemeli sistemden modüler sisteme geçiş yapılmışıtır. Bu bağlamda bu çalışma hem ilerlemeli hem de modüler sistemde hazırlık sınıflarında görev almış akademisyenlerin her iki sistemin güçlü ve zayıf yanları ile ilgili görüş ve değerlendirmelerini almayı amaçlamıştır. Çalışmaya 23 akademisyen katılmış ve yarı-yapılandırılmış görüşme formu aracılığıyla veriler toplanmıştır. Çalışmanın bulgularına göre her iki sistemin de olumlu ve olumsuz yönleri bulunduğu ancak akademisyenler tarafindan modüler sistemin tercih edildiği sonucuna ulaşılmıştır.

Anahtar sözcükler: Hazırlık eğitimi; yabancı dil olarak İngilizce; yükseköğretim; modüler system; ilerlemeli sistem

\section{AUTHOR BIODATA}

Ali Erarslan works as an assistant professor in the department of English language teaching at Alanya Alaaddin Keykubat University. Prior to this, he worked in the School of Foreign Languages at Pamukkale University between 2007 and 2017. The author completed his MA at Pamukkale University and his Phd at Çanakkale Onsekiz Mart University in English language teaching. He had administrative roles in both universities he worked. His research interests are program evaluation, technology integrated language teaching, ESP and teacher education. 